Г. В. Стойкевич, О. І. Лебідь, Х. В. Погорецька, К. М. Дуда, Л. О. Пацкань ДВНЗ “Тернопільський державний медичний університет імені І. Я. Горбачевського МОЗ України”

\title{
ОСОБЛИВОСТІ ВИКЛАДАННЯ РОЗДІЛУ “ЗАХВОРЮВАННЯ ЕНДОДОНТА” В КУРСІ “ТЕРАПЕВТИЧНА СТОМАТОЛОГІЯ” ДЛЯ СТУДЕНТІВ ІІІ КУРСУ СТОМАТОЛОГІЧНОГО ФАКУЛЬТЕТУ
}

\author{
H. V. Stoikevich, O. I. Lebid, Kh. V. Pohoretska, K. M. Duda, L. O. Patskan \\ I. Horbachevsky Ternopil State Medical University \\ FEATURES OF TEACHING SECTION “ENDODONTIST DISEASES” \\ WITHIN THE COURSE “THERAPEUTIC DENTISTRY” FOR 3RD YEAR \\ STUDENTS OF FACULTY OF DENTISTRY
}

\begin{abstract}
Мета роботи - формування у студентів індивідуального підходу до кожного пацієнта, лікарського мислення, мотивації щодо вивчення матеріалу та постійного вдосконалення і поповнення теоретичних знань.

Основна частина. У статті подано особливості методики викладання розділу “Періодонтит” у курсі “Терапевтична стоматологія” студентам, які навчаються на стоматологічному факультеті, з урахуванням вимог кредитно-трансферної системи навчання.

Стаття розкриває проблему підготовки висококваліфікованих лікарів-стоматологів на профільних клінічних кафедрах у вищих медичних навчальних закладах. Поєднання теоретичної підготовки з можливістю попрактикуватись на реальних пацієнтах 3 відповідною клінічною ситуацією дає можливість закріпити знання і готувати компетентних майбутніх лікарів 3 дисципліни “Стоматологія".

Висновок. Чітка організація навчального процесу під час викладання розділу “Періодонтит” для студентів третього курсу стоматологічного факультету дозволить здобути відмінні практичні навички та вміння, а також створити міцне теоретичне підгрунтя, яке дасть можливість готувати кваліфікованих лікарів-стоматологів.
\end{abstract}

Ключові слова: навчальний процес; кредитно-трансферна система; стоматологія; захворювання ендодонта.

The aim of the work - to form an individual approach to each patient among students, medical thinking, motivation to study the material and continuous improvement and replenishment of theoretical knowledge.

The main body. The peculiarities of teaching the section "Periodontitis" within the "Therapeutic Dentistry" course for the Faculty of Dentistry students, taking into account the requirements of the credit-transfer system of training are represented in the article.

The issue of highly skilled dentistry specialists' training in specialized clinical departments at higher medical educational institutions is covered. The combination of theoretical training with the ability to practice with real patients with the relevant clinical situation, provides the opportunity to consolidate the knowledge and train competent future doctors on the "Dentistry" course.

Conclusion. The clear arrangement of the educational process during the "Periodontitis" section teaching for 3rd year students of the Faculty of Dentistry allows to get excellent practical skills and abilities, as well as create a solid theoretical foundation that will enable qualified dentists to be trained.

Key words: educational process; credit-transfer system; dentistry; endodontal diseases.

Вступ. Впровадження в організацію навчального процесу кредитно-трансферної системи відповідно до вимог Болонської конвенції в ДВНЗ “Тернопільський державний медичний університет імені I. Я. Горбачевського МОЗ України” стало поштовхом до реорганізації методики викладання профільних дисциплін, у тому числі терапевтичної стоматології як профільної дисципліни на стоматологічному факультеті [1].

(ㄷ Г. В. Стойкевич, О. І. Лебідь, Х. В. Погорецька та ін.
Незважаючи на прогресивний розвиток сучасної стоматології, захворювання ендодонта залишаються досить актуальними і займають близько $40 \%$ серед усіх захворювань зубів. Тому основним завданням залишається донести до студентів важливість даного розділу в процесі вивчення і підготовки майбутніх спеціалістів у цій галузі медицини.

Без сумніву, умовами поліпшення теоретичної і практичної підготовки майбутніх лікарів є створення позитивної мотивації щодо вивчення пред- 
мета та стимулювання студентів до самостійної навчально-пізнавальної діяльності. Важливою є також наявність достатньої матеріальної та клінічної бази, яка дає можливість у повному обсязі освоювати предмет.

Мета роботи - формування у студентів індивідуального підходу до кожного пацієнта, лікарського мислення, мотивації щодо вивчення матеріалу та постійного вдосконалення і поповнення теоретичних знань.

Основна частина. У статті подано особливості методики викладання розділу “Періодонтит” у курсі “Терапевтична стоматологія” студентам, які навчаються на стоматологічному факультеті, з урахуванням вимог кредитно-трансферної системи навчання.

У межах предмета “Терапевтична стоматологія” виділяють окремий розділ “Одонтологія”, який присвячений патології твердих тканин зубів, пульпи та періодонта. Цей розділ складається 3 60 занять, до складу яких входять чотири підрозділи. Четвертий підрозділ “Періодонтит” є одним із складових частин блоку занять “Захворювання ендодонта”. Заняття проводяться згідно зі стрічковою системою.

Розділ “Періодонтит” складається із п’ятнадцяти занять, які спрямовані на освоєння етіології, патогенезу, клініки, діагностики, всіх існуючих методів лікування та профілактики захворювань верхівкового періодонта. В процесі проведення заняття студенти опановують практичні навички відповідно до методичних вказівок теми заняття. Студент має оволодіти навичками обстеження хворого, навчитись діагностики, диференційної діагностики та вміння застосовувати основні методи лікування і профілактики захворювань періодонта. Завдяки розробленим викладачами кафедри методичним рекомендаціям для викладачів та методичним вказівкам для студентів, де оволодіння практичними навичками поєднано з освоєнням та закріпленням теоретичного матеріалу, майбутні лікарі мають можливість у ході заняття з легкістю виконувати всі поставлені перед ними завдання. У методичних вказівках висвітлюється професійна орієнтація студентів, містяться грунтовно написаний зміст теми, мета та завдання, які поставлені перед студентом [2]:

1) ознайомитись із сучасними уявленнями про етіологію та патогенез періодонтитів;

2) засвоїти основні принципи патоморфології, клініки й диференційної діагностики гострих та хронічних періодонтитів;
3) ознайомитись із методиками лікування гострого та хронічного періодонтитів, сучасними технологіями, прискореними методами лікування періодонтиту;

4) ознайомити студентів із використанням фізичних методів у діагностиці та лікуванні карієсу та його ускладнень, методикою їх проведення;

5) навчитись ефективно проводити лікування періодонтиту й у разі виникнення ускладнень у лікуванні негайно їх усувати.

Заняття розпочинається з визначення вихідного рівня знань. Викладач може опитувати студентів в усній формі, шляхом розв’ язування ситуаційних задач. Для цього працівниками кафедри розроблені ситуаційні задачі й тести, які виконують не лише контролюючу функцію, але й дозволяють розвивати логічне мислення та тактику у вирішенні певної клінічної ситуації.

Після теоретичного опитування студенти приступають до практичної роботи, яка відповідає темі й орієнтована на здобування достатніх практичних навичок [3]. У ході виконання практичної роботи викладач оцінює можливість студентів аналізувати клініко-анатомічні особливості перебігу гострих та хронічних періодонтитів різної етіології, вміння провести основні й додаткові методи обстеження у хворого з патологією періодонта, інтерпретувати результати рентгенівського обстеження, проводити диференційну діагностику захворювань періодонта, провести всі лікувальні маніпуляції в кореневих каналах та грамотно надати рекомендації. Основним завданням, яке стоїть перед студентом у процесі лікування періодонтитів, є усунення вогнища інфекції в періодонті, якісна обтурація кореневого каналу, відновлення анатомічної форми та функції зуба.

Для того щоб студент зумів вдало провести лікування, перед керівництвом вузу та безпосередньо кафедрою стоїть завдання забезпечити навчальний процес необхідним обладнанням та розхідними матеріалами.

Студенти працюють безпосередньо з пацієнтами, які звернулись на кафедру з відповідними скаргами. У ході первинного обстеження студент визначає стоматологічний статус, здобуває вміння налагоджувати контакт із пацієнтом залежно від його психоемоційного стану, вчиться етики та деонтології. Під контролем викладача виконує маніпуляції відповідно до клінічної ситуації. Для практичної частини виділяється близько 2/3 часу, який виділений на заняття. За відсутності пацієнта студенти працюють із фантомами. 
Для роботи надаються необхідні матеріали та сучасний інструментарій. Студенти навчаються працювати відповідно до протоколів надання допомоги [4].

На заключному етапі заняття викладач проводить контроль і корекцію професійних знань та умінь студентів у групі, оцінює успішність і визначає завдання для самостійної підготовки до наступного заняття.

Висновки. 1. Чітка організація навчального процесу під час викладання розділу “Періодонтит” для студентів третього курсу стоматологічного факуль-

\section{Список літератури}

1. Данилевский Н. Ф. Распространенность основных стоматологических заболеваний и состояние гигиены полости рта у населения различных регионов Украины (по обращаемости) / Н. Ф. Данилевский, Л. Ф. Сидельникова, А. Г. Ткаченко // Современная стоматология. 2003. - № 3. - С. 14-16.

2. Програма навчальної дисципліни для студентів стоматологічних факультетів вищих медичних навчальних закладів IV рівня акредитації за спеціальністю 7.110106 “Стоматологія” / [А. К. Ніколішин, А. В. Борисенко та ін.]. - K., 2011. - 117 с.

\section{References}

1. Danilevskiy, N.F., Sidelnikova, L.F., \& Tkachenko, A.G. (2003). Rasprostranennost' osnovnykh stomatologicheskikh zabolevaniy i sostoyaniye gigiyeny polosti rta u naseleniya razlichnykh regionov Ukrainy (po obrashchayemosti) [The prevalence of major dental diseases and the state of oral hygiene among the population of different regions of Ukraine (by referral)]. Sovremennaya stomatologiya Modern Dentistry, 3, 14-16 [in Russian].

2. Nikolishyn, A.K., \& Borysenko, A.V. (2011). Prohrama navchalnoi dystsypliny dlia studentiv stomatolohichnykh fakultetiv vyshchykh medychnykh navchalnykh zakladiv IV rivnia akredytatsii za spetsialnistiu 7.110106 "Stomatolohiia" [The syllabus of the discipline for students of the dental faculties of the higher medical educational institutions of the IV accreditation level in the specialty 7.110106 “Dentistry”]. Kyiv [in Ukrainian]. тету дозволить здобути відмінні практичні навички та вміння, а також створити міцне теоретичне підгрунтя, яке дасть можливість готувати кваліфікованих лікарів-стоматологів.

2. Розв’язання ситуаційних задач дозволяє студентам розвивати логічне мислення та тактику у вирішенні певної клінічної ситуації. У ході виконання практичної роботи викладач має можливість контролювати процес, оцінювати роботу студента, аналізувати й у разі необхідності допомогти.

3. Опанасюк Ю. В. Протоколи надання стоматологічної допомоги / Ю. В. Опанасюк. - К. : ТОВ Видавничо-інформаційний центр “Світ сучасної стоматології”, 2005. - 507 c.

4. Про внесення змін до наказу МОЗ України від 25.07.2007 р. № 352 “Про затвердження та введення нового навчального плану підготовки фахівців за спеціальністю “Стоматологія”: наказ МОЗ України від 23.07.2007 p. № 415.

3. Opanasiuk, Yu.V. (2005). Protokoly nadannia stomatolohichnoi dopomohy [Protocols for the provision of dental care]. Kyiv: TOV Vydavnycho-informatsiinyi tsentr "Svit suchasnoi stomatolohii” [in Ukrainian].

4. Pro vnesennia zmin do nakazu MOZ Ukrainy vid 25.07.2007 r. № 352 “Pro zatverdzhennia ta vvedennia novoho navchalnoho planu pidhotovky fakhivtsiv za spetsialnistiu "Stomatolohiia”: nakaz MOZ Ukrainy vid 23.07.2007 r. № 415 [Concerning the Introduction of Amendments to Order of MH of Ukraine № 352 of July 25, 2007 "On Approval and Introduction of a New Curriculum for the Training of Specialists in the field of Dentistry": Order № 415 of the MH of Ukraine of July 23, 2007] [in Ukrainian]. 